\title{
Association between insulin-like growth factor-I, thyroxine and follicle stimulating hormone on the survival and in vitro development of caprine preantral follicles*
}

\section{Associação entre fator de crescimento semelhante à insulina-I, tiroxina e hormônio folículo estimulante sobre a sobrevivência e o desenvolvimento in vitro de folículos pré-antrais caprinos}

\author{
Sanely Lourenço da Costa, ${ }^{* *}$ Eduardo Paulino da Costa, ${ }^{* *}$ Emílio César Martins Pereira, ${ }^{* * *}$ \\ Wagner Gonzaga Gonçalves, ${ }^{* * * *}$ Talita Fernandes da Silva, ${ }^{* *}$ Vanessa Lopes Dias Queiroz ${ }^{* *}$
}

\begin{abstract}
Abstrat
The aim of this study was to investigate the influence of the interaction between follicle stimulating hormone obtained from Human

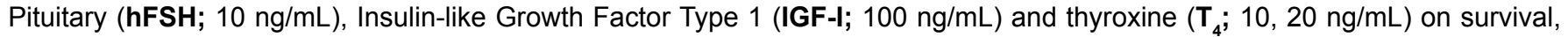
activation and growth of preantral follicles (PAF) cultured in vitro. Fragments of ovarian cortex collected from 17 nonpregnant adult goats underwent different treatments that included $\alpha-\mathrm{MEM}^{+}$medium, IGF-I, hFSH, $\mathrm{T}_{4}$ and were processed for classic histology and transmission electron microscopy. The results showed a reduction in the percentage of normal follicles, after one and seven days of culture in media $\alpha-\mathrm{MEM}^{+}$(cultured control), $\mathrm{T}_{4}(10) / \mathrm{IGF}-\mathrm{I}, \mathrm{T}_{4}(20) / / \mathrm{IGF}-\mathrm{I} / \mathrm{hFSH}$ and in media $\alpha-\mathrm{MEM}^{+}, \mathrm{IGF}^{\mathrm{I}} \mathrm{I} / \mathrm{hFSH}, \mathrm{T}_{4}(20) / / \mathrm{IGF}-\mathrm{I} / \mathrm{hFSH}$, $\mathrm{T}_{4}(20) / / G F-1 / h F S H$ when compared to the non-cultured control. However, the medium containing $\mathrm{T}_{4}(20) / \mathrm{hFSH}$ showed a follicular survival rate higher than the other treatments, when cultured for seven days. It was also observed that the follicular diameter did not change when cultured in this medium, when compared to the control (non-cultured). The ultrastructural analysis confirmed the integrity of follicles cultured in a medium containing $\mathrm{T}_{4}(20) / \mathrm{hFSH}$. In conclusion, the medium containing $\mathrm{T}_{4}(20) / \mathrm{hFSH}$ showed the best results, when evaluating the survival, growth and ultrastructural aspects of caprine preantral follicles cultured in vitro.
\end{abstract}

Keywords: Caprine, hormone, in vitro culture, preantral follicles, ultrastructural analysis.

\section{Resumo}

O objetivo deste estudo foi investigar a influência da interação entre o Hormônio Folículo Estimulante obtido da pituitária Humana (hFSH; $10 \mathrm{ng} / \mathrm{mL}$ ), Fator de Crescimento Semelhante a Insulina Tipo 1 (IGF-I; 100 ng/mL) e Tiroxina (T); 10, 20 ng/mL) na sobrevivência, ativação e crescimento de folículos pré-antrais cultivados in vitro. Fragmentos do córtex ovariano coletados a partir de 17 cabras adultas não gestantes foram submetidos a diferentes tratamentos que incluíam meio $\alpha-M_{\text {MMM }}^{+}$. IGF-I, hFSH, $\mathrm{T}_{4}$ e em seguida foram processados para histologia clássica e microscopia eletrônica de transmissão. Os resultados demonstraram uma redução no percentual de folículos normais, após um e sete dias de cultivo nos meios $\alpha-\mathrm{MEM}^{+}$(controle cultivado), $\mathrm{T}_{4}(10) / \mathrm{IGF}-\mathrm{I}$, $\mathrm{T}_{4}(20) / / \mathrm{IGF}-\mathrm{I} / \mathrm{hFSH}$ e nos meios $\alpha-\mathrm{MEM}^{+}$, IGF-I/hFSH, $\mathrm{T}_{4}(20) / / \mathrm{GF}-\mathrm{I} / \mathrm{hFSH}, \mathrm{T}_{4}(20) / \mathrm{IGF}-\mathrm{l} / \mathrm{hFSH}$ quando comparados ao controle não cultivado. Entretanto, o meio contendo $\mathrm{T}_{4}(20) / \mathrm{hFSH}$ apresentou taxa de sobrevivência folicular superior aos demais tratamentos, quando cultivado por sete dias. Observou-se, ainda, que o diâmetro folicular quando cultivado neste meio não se alterou, quando comparado ao controle (não cultivado). As análises ultraestruturais confirmaram a integridade de folículos cultivados em meio contendo $\mathrm{T}_{4}(20) / \mathrm{hFSH}$. Em conclusão, o meio com $\mathrm{T}_{4}(20) / \mathrm{hFSH}$ apresentou os melhores resultados, quando se avaliou sobrevivência, crescimento e aspectos ultraestruturais de folículos pré-antrais de caprinos cultivados in vitro.

Palavras-chave: Análise ultraestrutural, caprinos, cultivo in vitro, folículos pré-antrais, hormônios.

\section{Introduction}

In order to maximize the reproductive potential of the ovarian tissue, it is necessary to develop culture strategies that support the activation and sustain the in vitro growth of primordial follicles, in view of the abundance of this class of follicles in the ovarian tissue (Picton et al., 2008). The progress in culture systems that can support the growth and development of preantral follicles (PAF) in domestic species has been slow when compared to results in mice, for which a complete growth can be obtained (O’Brien et al., 2003).

Recent studies have demonstrated that insulin-like growth factor-I (IGF-I) plays an important role in the development of PAF and inhibits the process of follicular atresia. When added during the in vitro culture of PAF, IGF-I stimulates follicle growth of human (Louhio et al., 2000), cattle (Gutierrez et al., 2000) and rats (Zhao et al., 2001) ovarian tissue, in synergy with follicle

\footnotetext{
${ }^{*}$ Recebido em 10 de maio de 2014 e aceito em 10 de junho de 2014.

**Universidade Federal de Viçosa (UFV), Departamento de Veterinária, Laboratório de Maturação de Ovócitos e Fertilização In Vitro (Mofiv), Viçosa, MG, Brazil.

***Universidade Estadual Paulista Júlio Mesquita Filho (UNESP), Departamento de Reprodução Animal e Radiologia Veterinária, Botucatu, SP, Brazil.

****Universidade Federal de Viçosa (UFV), Departamento de Biologia Geral, Viçosa, MG, Brazil.

Author for correspondence. E-mail: sanelylc@hotmail.com
} 
stimulating hormone (FSH). In rats, IGF-I significantly increases follicular diameter and DNA content, when added during the in vitro culture of PAF (Zhao et al., 2001). Among the substances that participate in early folliculogenesis FSH and thyroxine $\left(\mathrm{T}_{4}\right)$ deserve to be highlighted. Some in vitro studies demonstrated that the addition of FSH to the culture medium promotes apoptosis inhibition and antrum formation in large secondary follicles of different species (ovine: Cecconi et al., 1999; bovine: Gutierrez et al., 2000; swine: Mao et al., 2002). FSH is also capable of regulating the expression of various growth factors such as Kit Ligand (KL), Growth differentiation factor-9 (GDF9) and Bone Morphogenetic Protein-15 (BMP-15), participating in the activation and follicular growth (Thomas et al., 2005). It has been noted the participation of thyroid hormones $\left(T_{3}\right.$ and $\mathrm{T}_{4}$ ) on ovarian folliculogenesis and steroidogenesis (Cecconi et al., 2004), promoting differentiation of granulosa cells (Silva et al., 2004) and ovulation stimulation (Serakides et al., 2001).

The present study was designed aiming to investigate the influence of the interaction between FSH obtained from Human pituitary (hFSH; $10 \mathrm{ng} / \mathrm{mL})$, IGF-I ( $100 \mathrm{ng} / \mathrm{mL})$ and $\mathrm{T}_{4}(10$ or 20 $\mathrm{ng} / \mathrm{mL}$ ) on the survival, activation and growth of preantral follicles cultured in vitro. These concentrations were used after a previous study performed by our team, in which promising results were obtained when cultured in vitro.

\section{Materials and methods}

This study was approved by the Ethics Committee on Animal Use, CEUA-UFV under case $n^{\circ} 45 / 2012$ on August 06, 2012. Ovaries $(n=34)$ from 17 adult nonpregnant mixedbreed goats (1-3 years of age) were collected from a local slaughterhouse. Immediately postmortem, the ovaries were washed in $70 \%$ alcohol for 10 seconds and then washed again in MEM supplemented with $100 \mu \mathrm{g} / \mathrm{mL}$ penicillin and $100 \mu \mathrm{g} /$ $\mathrm{mL}$ streptomycin. The pairs of ovaries were transported to the laboratory in MEM at $4{ }^{\circ} \mathrm{C}$ within $1 \mathrm{~h}$ postmortem. Unless otherwise mentioned, all chemicals used in the present study were purchased from Sigma Chemical Co. (St Louis, USA).

The organ culture system utilized herein was previously described in detail (Matos et al., 2007; Celestino et al., 2010). In the laboratory, the ovaries from each animal were stripped of surrounding fat tissue and ligaments. Subsequently, ovarian cortex tissue samples from each ovarian pair were cut into 9 slices (approximate size: $3 \times 3 \mathrm{~mm}$, with $1 \mathrm{~mm}$ thickness) using a scalpel under sterile conditions. The tissue pieces were then either fixed for histological and ultrastructural analysis (fresh control) or placed in culture for one and seven days. Caprine tissues were transferred to 24-well culture dishes containing 1 $\mathrm{mL}$ of culture media. Culture was performed at $39^{\circ} \mathrm{C}$ in $5 \% \mathrm{CO}_{2}$ in a humidified incubator and all the media were incubated for one hour prior to use. The basic culture medium consisted of a-MEM (pH 7.2 to 7.4 ) supplemented with ITS $(10 \mu \mathrm{g} / \mathrm{mL}$ insulin, $5.5 \mu \mathrm{g} / \mathrm{mL}$ transferrin and $5 \mathrm{ng} / \mathrm{mL}$ selenium), $2 \mathrm{mM}$ glutamine, $2 \mathrm{mM}$ hypoxanthine, $1.25 \mathrm{mg} / \mathrm{mL}$ bovine serum albumin (BSA), which was called $\alpha-M^{-} M^{+}$.

For the experimental conditions, the ovarian cortex fragments were cultured in $\alpha-M E M+$ alone (culture control) and $\alpha-M E M+$ supplemented with different concentrations of hFSH $(10 \mathrm{ng} /$ $\mathrm{mL})$, IGF-I $(100 \mathrm{ng} / \mathrm{mL})$ or $\mathrm{T}_{4}(10$ or $20 \mathrm{ng} / \mathrm{mL})$ in association as showed in the Table 1. Each treatment was repeated seventeen times and the culture media was changed every 2 days.
Table 1: Different media tested for the in vitro culture of caprine preantral follicles

\begin{tabular}{|c|c|}
\hline Culture medium & Abbreviation \\
\hline a-MEM ${ }^{+}$(culture control) & $\alpha-\mathrm{MEM}^{+}$ \\
\hline$\alpha-M^{\prime} M^{+}(I G F-I+h F S H)$ & IGF-I/hFSH \\
\hline$\alpha-\mathrm{MEM}^{+}\left(\mathrm{T}_{4}+\mathrm{hFSH}\right)$ & $\mathrm{T}_{4} / \mathrm{hFSH}$ \\
\hline$\alpha-M^{\prime} M^{+}\left(T_{4}+\right.$ IGF-I $)$ & $\mathrm{T}_{4} /$ IGF-I \\
\hline$\alpha-\mathrm{MEM}^{+}\left(\mathrm{T}_{4}+\right.$ IGF-I $\left.+\mathrm{hFSH}\right)$ & $\mathrm{T}_{4} / \mathrm{IGF}-\mathrm{I} / \mathrm{hFSH}$ \\
\hline
\end{tabular}

Before culture (fresh control) and after one and seven days in culture, all tissue pieces were fixed in Carnoy's solution for four hours and then dehydrated in increasing concentrations of ethanol. After paraffin embedding, the caprine ovarian cortex tissues were cut into $7 \mu \mathrm{m}$ sections, which were mounted on glass slides and stained by Periodic Acid Schiff (PAS) - hematoxylin. Follicle stage and morphology were assessed microscopically on serial sections. Coded anonymized slides were examined by a microscope (Olympus ${ }^{\circledR}$ ) under $400 x$ magnification.

The developmental stages of follicles have been defined previously (Silva et al., 2004) as primordial (one layer of flattened granulosa cells around the oocyte) or growing follicles (intermediate: one layer of flattened and cuboidal granulosa cells; primary: one layer of cuboidal granulosa cells; and secondary: two or more layers of cuboidal granulosa cells around the oocyte). Only the PAF (primordial, intermediate, primary and secondary) were considered in the analysis. The PAF were also classified individually as histologically normal when an intact oocyte was present, surrounded by granulosa cells that were well organized in one or more layers and lacked a pyknotic nucleus. Degenerated follicles were defined as those with a retracted oocyte, pyknotic nucleus, and/or disorganized granulosa cells detached from the basement membrane. Overall, 510 follicles were evaluated for each treatment ( 30 follicles per treatment in one repetition $\mathrm{x}$ seventeen repetitions $=510$ follicles).

To evaluate follicular activation, the percentages of healthy primordial and growing follicles were calculated before (fresh control) and after culture in each medium. In addition, follicle and oocyte diameters were measured in healthy follicles only. Follicle diameter was recorded from edge to edge of the outer layer of granulosa cells or from the outside edge of the theca cell layer when present. Oocyte diameter was recorded from edge to edge of the oocyte membrane. Two perpendicular diameters were recorded in each measurement and the average of these two values was calculated. Each follicle was examined in every section in which it appeared and matched with the same follicle on adjacent sections to avoid double counting.

To better evaluate follicular morphology, ultrastructural analysis was performed on PAF from non-cultured tissue (fresh control), follicles cultured in the treatments that had the best results for morphology, activation and growth. Briefly, small pieces (1 $\mathrm{mm}^{3}$ ) of caprine ovarian tissues were fixed for four hours at room temperature in karnovsky fixative $(2.5 \%$ glutaraldehyde and $4 \%$ formaldehyde in $0.1 \mathrm{M}$ cacodylate buffer, $\mathrm{pH} 7.2$ ). After fixation, the samples were washed twice in $0.1 \mathrm{M}$ cacodylate buffer, post-fixed in $1 \%$ osmium tetroxide, dehydrated in acetone, and embedded in Epon 812 resin. Afterwards, semithin sections $(3 \mu \mathrm{m})$ were cut using an ultramicrotome (MT2-B, 
Sorvall, USA), stained with toluidine blue and analyzed by light microscopy under $400 x$ magnification. Ultra-thin sections (60 to $70 \mathrm{~nm}$ ) were obtained from PAF classified as morphologically normal in semi-thin sections, according to the criteria adopted for histological analysis. Subsequently, ultra-thin sections were contrasted with uranyl acetate and lead citrate, and examined under a transmission electron microscope EM 109 Zeiss (Berlin, Germany) operating at 80 Kv (Donato et al., 2009). Parameters such as the density and integrity of ooplasmic and granulosa cell organelles, vacuolization and integrity of the basement membrane were evaluated.

The variables were submitted to Normality (Lilliefors) and Homoscedasticity (Cochran) tests and posteriorly to the analysis of variance at a probability of $5 \%$. In case a significance was presented, the Duncan test was carried out (ANOVA; SAS, 2002).

\section{Results and discussion}

\section{Caprine preantral follicle survival before and after in vitro culture}

A total of 5,610 preantral follicles were analyzed by classic histology. Figures (1A, B and C) show normal follicles of control ovarian tissue (non-cultured), and after the culture for seven days in $\alpha-\mathrm{MEM}^{+}$supplemented with $\mathrm{T}_{4}(20) / \mathrm{hFSH}$ and cultured for one day, in medium containing $T_{4}(20) / / G F-I$, respectively. Figures (1
$D, E$ and $F$ ) illustrate degenerated follicles after the culture in a-MEM ${ }^{+}$for seven days (cultured control) or follicles of ovarian tissue cultured for seven days in medium containing IGF-I/ $\mathrm{hFSH}$ and medium containing $\mathrm{T}_{4}(20) / / \mathrm{GF}-\mathrm{l} / \mathrm{hFSH}$, respectively. In degenerated follicles retracted oocytes and disorganization of granulosa cells were observed.

The percentages of morphologically normal preantral follicles in the fresh control and after the in vitro culture are presented in Table 2. After one day of culture, there was a reduction $(P<0.05)$ in the percentage of morphologically normal follicles in tissues cultured in $\alpha-\mathrm{MEM}^{+}$(control), in medium containing $\mathrm{T}_{4}(10) / \mathrm{IGF}-\mathrm{I}$ and $\mathrm{T}_{4}(20) / \mathrm{IGF}-\mathrm{I} / \mathrm{hFSH}$ compared to the fresh control (96.7\%). The culture in the other media maintained the percentage of normal follicles, when compared to the fresh control $(P>0.05)$.

However, on day seven of culture, the media supplemented with $\mathrm{T}_{4}(10) / \mathrm{hFSH}, \mathrm{T}_{4}(20) / \mathrm{hFSH}, \mathrm{T}_{4}(10) / \mathrm{IGF}-\mathrm{I}$ and $\mathrm{T}_{4}(20) / \mathrm{IGF}-\mathrm{I}$ maintained the percentage of normal follicles equivalent to the fresh control $(P>0.05)$. When the media were compared among themselves, there was no difference $(P>0.05)$ in the rate of normal follicles, when culturing the tissues for one day. However, with seven days of culture, the media containing $\mathrm{T}_{4}(20) / \mathrm{hFSH}$ was superior $(P<0.05)$ to the $\alpha-M^{2} M^{+}, I G F-I / h F S H$ and $T_{4}(10) /$ IGF-I/hFSH media. With the progression of culture from one to seven days, all treatments maintained $(P>0.05)$ the percentage of normal follicles.
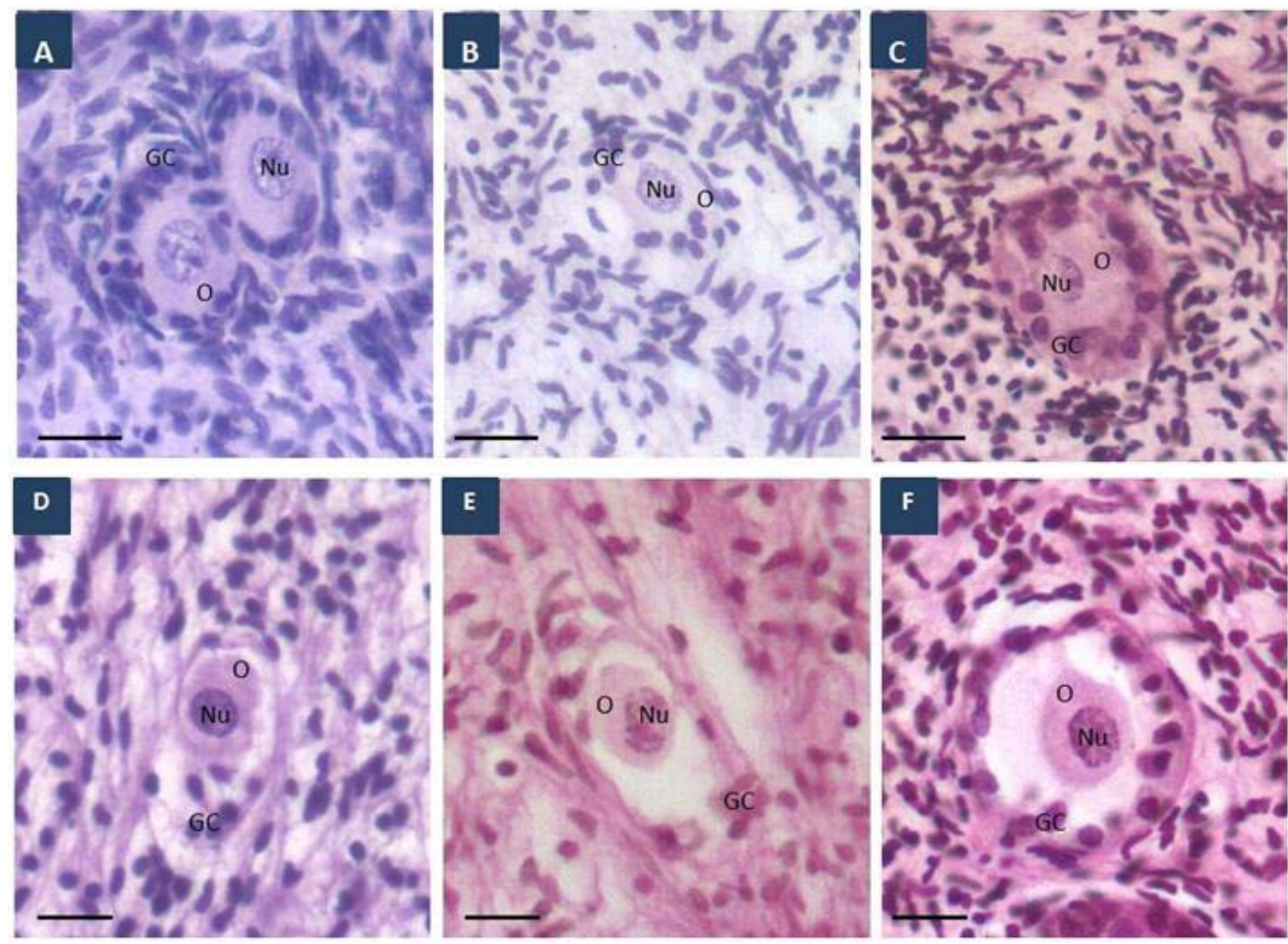

Figure 1: Histological sections of ovarian tissue fragments after staining with Periodic Acid-Schiff's hematoxylin showing morphologically normal follicles (A, fresh control), (B, $\left.\mathrm{T}_{4}(20) / \mathrm{hFSH}\right)$ e $\left(\mathrm{C}, \mathrm{T}_{4}(20) / / \mathrm{IGF}-\mathrm{I}\right)$. The degenerated follicles were represented in the letters $\left(\mathrm{D}, \alpha-\mathrm{MEM}^{+}\right)$; $(\mathrm{E}, \mathrm{IGF}-\mathrm{I} / \mathrm{hFSH})$ and $\left(\mathrm{F}, \mathrm{T}_{4}(20) / / \mathrm{GF}-\mathrm{I} / \mathrm{hFSH}\right)$. O: oocyte, Nu: nucleus of the oocyte, GC: granulosa cells (Original magnification 200x). Scale bars represent $20 \mu \mathrm{m}$ 
Table 2: Percentage (mean \pm SEM) of morphologically normal preantral follicles in the fresh control (non-cultured) and after in vitro culture for one or seven days in the absence or presence of $\mathrm{T}_{4} / \mathrm{IGF}-\mathrm{I} / \mathrm{hFSH}$ (concentrations in $\mathrm{ng} / \mathrm{mL}$ )

\begin{tabular}{|c|c|c|c|}
\hline Treatments & Day 0 & Day 1 & Day 7 \\
\hline Fresh control & $96.7 \pm 0.5$ & & \\
\hline a-MEM ${ }^{+}$ & & $87.3 \pm 1.5^{* \mathrm{aA}}$ & $83.1 \pm 1.8^{*} \mathrm{CA}$ \\
\hline IGF-I/hFSH & & $88.9 \pm 2.9$ aA & $85.6 \pm 2.2^{\mathrm{tbcA}}$ \\
\hline $\mathrm{T}_{4}(10) / \mathrm{hFSH}$ & & $93.3 \pm 1.4^{\mathrm{aA}}$ & $89.2 \pm 2.1^{\mathrm{abA}}$ \\
\hline $\mathrm{T}_{4}(20) / \mathrm{hFSH}$ & & $88.3 \pm 4.0^{\mathrm{aA}}$ & $94.2 \pm 0.8^{\mathrm{aA}}$ \\
\hline $\mathrm{T}_{4}(10) /$ IGF-I & & $86.7 \pm 3.0^{* a A}$ & $93.3 \pm 1.4^{\mathrm{abA}}$ \\
\hline $\mathrm{T}_{4}(20) /$ IGF-I & & $91.7 \pm 1.0 \mathrm{aA}$ & $92.5 \pm 1.6 \mathrm{abA}$ \\
\hline $\mathrm{T}_{4}(10) / / \mathrm{GF}-\mathrm{I} / \mathrm{hFSH}$ & & $88.9 \pm 2.2^{\mathrm{aA}}$ & $85.6 \pm 4.8^{* \mathrm{bcA}}$ \\
\hline $\mathrm{T}_{4}(20) / \mathrm{IGF}-\mathrm{I} / \mathrm{hFSH}$ & & $84.4 \pm 9.1^{* \mathrm{aA}}$ & $87.8 \pm 2.2^{* a b c A}$ \\
\hline
\end{tabular}

${ }^{*}$ Differs significantly from control follicles $(P<0.05)$; $a, b$ differs significantly among concentrations in each day of culture $(P<0.05) ; A, B$ differs significantly with the progression of the culture period from day 1 to 7 in the same treatment $(P<0.05)$

\section{Activation of caprine primordial follicles after in vitro culture}

The percentages of primordial and developing follicles in fresh ovarian tissue were $59.8 \%$ and $36.9 \%$, respectively (Figure 2). After the culture, all media tested were similar to the noncultured control in primordial follicles and developing follicles $(P>0.05)$. When the media were compared among themselves, no difference $(P>0.05)$ was observed in both primordial and developing follicles. Additionally, with the progression of the culture period from one to seven days, no differences in the percentages of primordial and developing follicles were observed $(\mathrm{P}>0.05)$.

\section{In vitro growth of caprine preantral follicles}

There was a reduction $(P<0.05)$ in the oocyte diameter in all media, when the ovarian tissues were cultured for seven days (Table 3), except for the medium supplemented with $\mathrm{T}_{4}(20) /$ hFSH $(P>0.05)$. Regarding the follicular diameter, the culture for one day in $\alpha-\mathrm{MEM}^{+}$(cultured control) and $\mathrm{T}_{4}(20) / \mathrm{hFSH}$ media remained similar $(P>0.05)$ to the non-cultured control. When the media were compared among themselves on day one of culture, the concentration of $\mathrm{T}_{4}(20) / \mathrm{hFSH}$ was superior $(\mathrm{P}<0.05)$, except for the $\alpha-\mathrm{MEM}^{+}$(cultured control) in oocyte and follicular diameter. However, on day seven of culture, only the medium supplemented with $\mathrm{T}_{4}(20) / \mathrm{hFSH}$ remained similar to the noncultured control $(P>0.05)$.

However, when comparing the media among themselves on day seven of culture, the medium supplemented with $\mathrm{T}_{4}(20) / \mathrm{hFSH}$ remained superior $(P<0.05)$ than the other treatments, both in oocyte and follicular diameter. With the progression of the culture from one to seven days, the medium containing IGF-I/hFSH showed a decrease $(P<0.05)$ in the oocyte and follicular diameter, while the medium supplemented with $\mathrm{T}_{4}(10) / / G F-I$ made possible an increase in the oocyte diameter $(P<0.05)$.

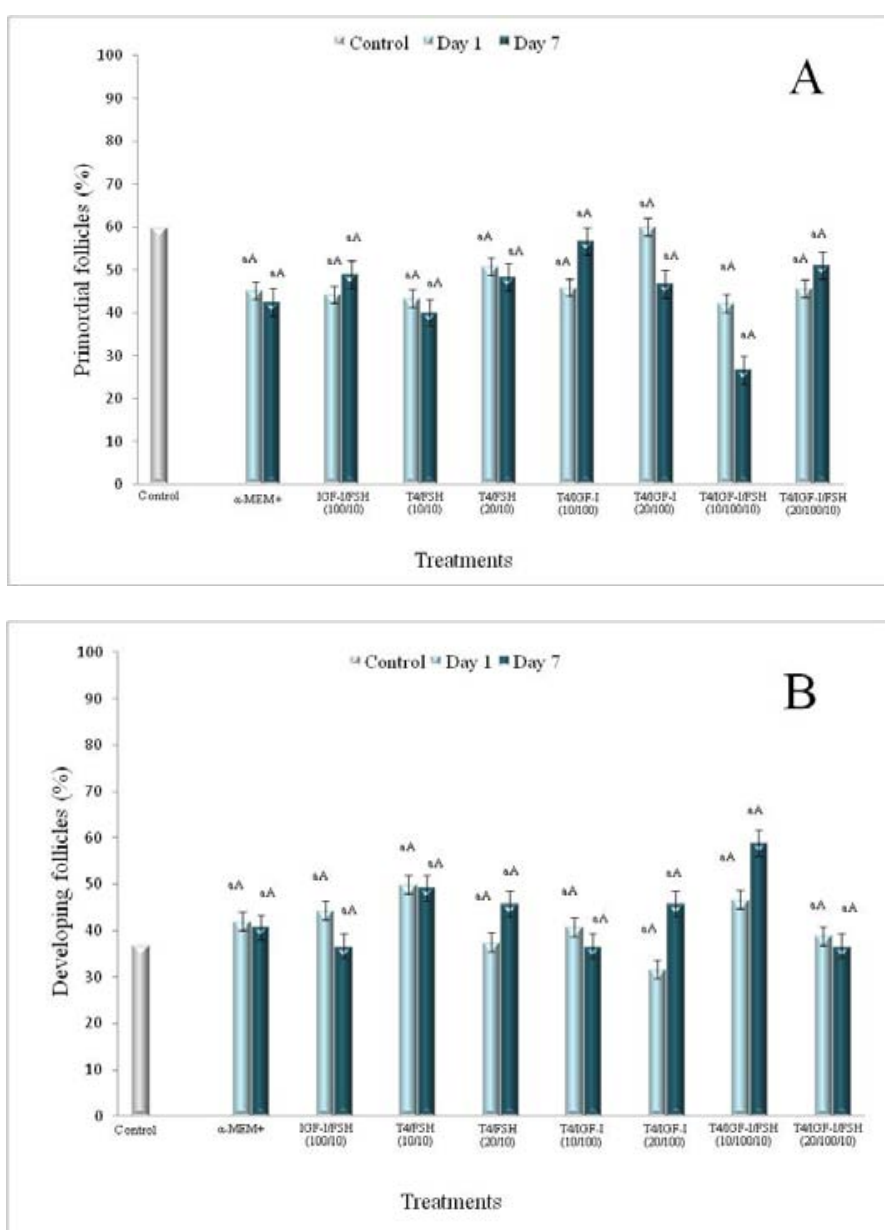

Figure 2: Percentage (mean \pm SEM) of primordial (A) and developing follicles (intermediate, primary and secondary) (B) in non-cultured (fresh control) and tissues cultured for one or seven days in the absence or presence of interaction $\mathrm{T}_{4} / \mathrm{IGF}-\mathrm{l} / \mathrm{hFSH}$ (concentrations in $\mathrm{ng} / \mathrm{mL}$ ) "Differs significantly from control follicles $(P<0.05)$; ${ }^{a}, b$ differs significantly among concentrations in each day of culture $(P<0.05) ; A, B$ differs significantly with the progression of the culture period from day 1 to 7 in the same treatment $(P<0.05)$.

\section{Ultrastructural features of caprine preantral follicles}

The ultrastructural analysis was performed on preantral follicles of the non-cultured control and follicles cultured in medium containing $\mathrm{T}_{4}(20) / \mathrm{hFSH}$, considering that this medium showed the best results in the parameters evaluated by histological analysis.

The follicles of the non-cultured control revealed an intact nuclear envelope, with a large nucleus of the oocyte. Moreover, the organelles, particularly the mitochondria and endoplasmic reticulum, were evenly distributed in the cytoplasm. Additionally, the granulosa cells were well arranged around the oocyte, showing a large and elongated nucleus (Fig. 3A). When cultured for seven days in medium with $\mathrm{T}_{4}(20) / \mathrm{hFSH}$, Fig $3 \mathrm{~B}$ ), the ultrastructural characteristics of the follicles were similar to the non-cultured control (Fig. 3B).

The composition of the culture medium is an important factor for the development of preantral follicles and can mainly determine their survival. By demonstrating that the percentage 
Table 3: Caprine oocyte and follicle diameters (mean \pm SEM) in non-cultured tissues (fresh control) and in tissues cultured for one or seven days in the absence or presence of interaction $\mathrm{T}_{4} /$ IGF-I/hFSH (concentrations in $\mathrm{ng} / \mathrm{mL}$ )

\begin{tabular}{|c|c|c|c|c|c|c|}
\hline \multirow[b]{2}{*}{ Treatments } & \multicolumn{3}{|c|}{ Oocyte diameter $(\mu \mathrm{m})$} & \multicolumn{3}{|c|}{ Follicle diameter $(\mu \mathrm{m})$} \\
\hline & Day 0 & Day 1 & Day 7 & Day 0 & Day 1 & Day 7 \\
\hline $\begin{array}{l}\text { Fresh control } \\
\qquad \alpha-\mathrm{MEM}^{+}\end{array}$ & $27.9 \pm 0.4$ & $24.1 \pm 0.4^{* a b A}$ & $23.4 \pm 0.5^{\mathrm{tbA}}$ & $37.1 \pm 0.7$ & $33.6 \pm 0.7^{\mathrm{abA}}$ & $31.4 \pm 0.8^{* \mathrm{bA}}$ \\
\hline IGF-I/hFSH & & $21.2 \pm 0.6^{* \mathrm{cde} A}$ & $18.8 \pm 0.6^{* \mathrm{~dB}}$ & & $28.4 \pm 1.0^{*} \mathrm{cdA}$ & $24.7 \pm 0.7^{\star \mathrm{dB}}$ \\
\hline $\mathrm{T}_{4}(10) / \mathrm{hFSH}$ & & $21.5 \pm 0.5^{\star c d A}$ & $20.7 \pm 0.4^{* \mathrm{cdA}}$ & & $29.3 \pm 1.3^{*} \mathrm{cdA}$ & $27.0 \pm 0.5^{* d A}$ \\
\hline $\mathrm{T}_{4}(20) / \mathrm{hFSH}$ & & $25.4 \pm 1.0^{*} \mathrm{aA}$ & $26.8 \pm 1.3^{\mathrm{aA}}$ & & $35.3 \pm 1.9^{\mathrm{aA}}$ & $36.6 \pm 2.2^{\mathrm{aA}}$ \\
\hline $\mathrm{T}_{4}(10) / \mathrm{IGF}-\mathrm{I}$ & & $20.2 \pm 0.5^{\star \mathrm{deB}}$ & $22.5 \pm 0.6^{* \mathrm{bcA}}$ & & $27.5 \pm 1.4^{* \mathrm{~cd} A}$ & $29.1 \pm 1.0^{*} \mathrm{bcA}$ \\
\hline $\mathrm{T}_{4}(20) / I G F-I$ & & $22.7 \pm 0.4^{* \mathrm{bcA}}$ & $21.6 \pm 0.3^{* \mathrm{bcA}}$ & & $30.6 \pm 0.8^{* \mathrm{bcA}}$ & $28.7 \pm 0.6^{* \mathrm{bcdA}}$ \\
\hline $\mathrm{T}_{4}(10) / / \mathrm{GF}-\mathrm{I} / \mathrm{hFSH}$ & & $20.1 \pm 0.5^{* \mathrm{deA}}$ & $21.3 \pm 0.7^{* \text { bcdA }}$ & & $26.6 \pm 0.7^{* \mathrm{cdA}}$ & $26.5 \pm 0.8^{* \mathrm{cdA}}$ \\
\hline $\mathrm{T}_{4}(20) / \mathrm{IGF}-\mathrm{I} / \mathrm{hFSH}$ & & $19.1 \pm 0.5^{*} \mathrm{AA}$ & $18.8 \pm 0.6^{* \mathrm{dA}}$ & & $25.9 \pm 0.7^{* \mathrm{dA}}$ & $24.7 \pm 0.7^{* \mathrm{dA}}$ \\
\hline
\end{tabular}

${ }^{*}$ Differs significantly from control follicles $(P<0.05)$; a,b differs significantly among concentrations in each day of culture $(P<0.05) ;{ }^{A, B}$ differs significantly with the progression of the culture period from day 1 to 7 in the same treatment $(P<0.05)$.
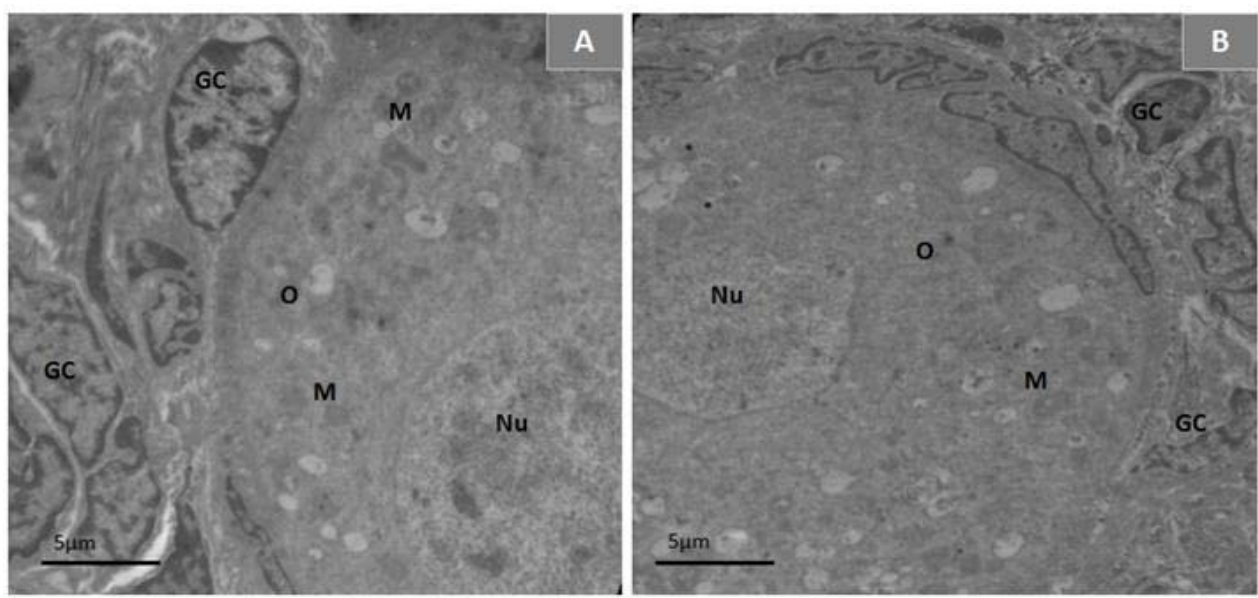

Figure 3: Ultrastructural analysis of preantral follicles from fresh control (A, 4.400x) and cultured for seven days $(B, 3.000 x)$ in medium containing $T_{4}(20) / h F S H$. Note homogeneous cytoplasm and mitochondria rounded, characteristic of the fresh control follicles (A and B). O: oocyte; Nu: oocyte nucleus; GC: granulosa cells; M: mitochondria. ( $A$ and $B=5 \mu \mathrm{m})$

of morphologically normal follicles in a-MEM+ (cultured control), $\mathrm{T}_{4}(10) / / \mathrm{IGF}-\mathrm{I}$ and $\mathrm{T}_{4}(20) / \mathrm{IGF}-\mathrm{I} / \mathrm{hFSH}$ media was lower than the fresh control (non-cultured tissue) on day one of culture, it is understood that the absence of hormonal supplementation in a-MEM control medium and the low concentration of $\mathbf{T}_{4}$ in the $\mathrm{T}_{4}(10) / / \mathrm{IGF}-\mathrm{I}$ treatment may have been insufficient to ensure the survival of follicles in the first place.

This fact can be justified mainly due to the fundamental role of $\mathrm{T}_{4}$ in the fertility of animals (Cheng et al., 2010), more specifically in preantral follicles. The importance of $T_{4}$ in the in vitro development of these has already been demonstrated in caprine (Rajarajan et al., 2006) and ovine (Arunakumari et al., 2007) species. In another extreme, the reduction in the percentage of normal follicles on day one in medium containing $\mathrm{T}_{4}(20) / \mathrm{IGF}-\mathrm{I} /$ $\mathrm{hFSH}$ corroborates with the findings by Arunakumari et al. (2010), in which the effect of the FSH, $\mathrm{T}_{4}$ and IGF-I combination did not provide an increase of matured oocytes (MII stage), although it had considerably elevated the proportion of preantral follicles showing growth, antrum formation and in vitro ovulation.

The base culture medium used in the culture of preantral follicles is commonly supplemented with various factors and substances, but the effectiveness of these additional factors on follicular survival and growth depends on the species studied, the concentrations used, the culture system and the number of days of culture (Rodrigues et al., 2010). In the face of this, the requirement of components for a culture medium of preantral follicles during seven days is greater, considering that it should ensure favorable growth conditions for this structure during its different stages of development and requirements.

Therefore, the superiority of the $T_{4}(20) / h F S H$ combination in comparison with $\alpha-\mathrm{MEM}^{+}$and IGF-l/hFSH, demonstrated in this study, makes clear the fundamental role of $T_{4}$ during the culture of preantral follicles over a longer period (Arunakumari et al., 2007). Therefore, the inferiority of the only two media that 
did not have $\mathrm{T}_{4}$ in their composition $\alpha-\mathrm{MEM}^{+}$and IGF-l/hFSH, confirms its need in the culture media, in order to ensure the follicular viability under these conditions.

Regarding the superiority of the rate of normal follicles observed in medium containing $\mathrm{T}_{4}(20) / \mathrm{hFSH}$, when compared to the medium supplemented with $\mathrm{T}_{4}(10) / / \mathrm{GF}-\mathrm{l} / \mathrm{hFSH}$, it can be associated to an overgrowth of the follicle of the latter treatment, by the synergistic action of $\mathrm{T}_{4}$, hFSH and IGF-I, not guaranteeing follicle survival. It is believed that this synergism elevates growth rates, antrum formation and diameter increase, in a proportion in which the medium is not capable of promoting an adequate nutritional support for the developing follicles, especially when they are cultured for a prolonged period. This fact has been previously described by Arunakumari et al. (2010) in media containing $T_{4}, F S H, I G F-I$ and Growth Hormone $(G H)$, and also by Zhao et al. (2000) in media containing $\mathrm{GH}$.

This experiment shows that, after the $1^{\text {st }}$ and $7^{\text {th }}$ day of culture, all media maintained a similar number of primordial and developing follicles, when compared to the cultured control medium $\left(\alpha-M^{2} M^{+}\right)$, showing no effect of the media on follicular activation. Our findings are similar to those obtained by Silva et al. (2006), which did not find any effect on follicular activation of media containing $\mathrm{FSH}$, despite having reported an increase in follicular and oocyte diameter. However, this finding differs from other studies (Martins et al., 2010; Saraiva et al., 2010) which, although they have worked with different culture media, they showed a reduction in the percentage of primordial follicles, concomitant with the increase in the percentage of developing follicles after one day of culture. The same authors showed that, after the $7^{\text {th }}$ day of culture, this reduction of primordial follicles and the elevation of developing follicles were even more striking and expressive. The data, found by these authors, allowed them to conclude that the growth factor present in the tested media was able to induce follicular activation (Martins et al., 2010). Similar results were found in goats (Silva et al., 2006; Matos et al., 2007). However, in this study, although no significant difference was found, this event was noted, on day one and seven of culture, in the $\mathrm{T}_{4}(20) / \mathrm{hFSH}, \mathrm{T}_{4}(20) / / \mathrm{IGF}-\mathrm{I}$ and $\mathrm{T}_{4}(10) / \mathrm{IGF}-\mathrm{I} / \mathrm{hFSH}$ media. Thus, it can be affirmed that the culture media tested in this study do not represent the essential factor for the activation of caprine preantral follicles cultured in vitro.

A set of morphological criteria are used to characterize the onset of the growth of primordial follicles, which consists of an increase in the oocyte diameter, proliferation of granulosa cells and transformation of the format of these cells form flat to cubic (Silva et al., 2006).

In domestic animals, FSH has the property of increasing the oocyte diameter and promoting the growth of preantral follicles, as well as stimulating the antrum formation and estrogen secretion (Cecconi et al., 1999; Silva et al., 2006). However, some authors reported that the presence of FSH in the in vitro culture medium induces an increase of the follicular diameter and antrum formation, but not of the oocyte growth (Gutierrez et al., 2000). Nevertheless, the $\mathrm{T}_{4}(20) / \mathrm{hFSH}$ association evaluated in this experiment was not able to increase the oocyte diameter after seven days of culture. This culture medium enabled a greater follicular diameter after the culture, when compared to the other media. These results corroborate with Arunakumari et al. (2010), who verified that the association of $\mathrm{FSH}$ with $\mathrm{T}_{4}$, although not promoting oocyte maturation, contributes to a significant increase for antrum formation, growth and ovulation of preantral follicles.

By comparing the media individually in accordance with the progression of the days of culture, from one to seven, there was a reduction in oocyte and follicular diameter with the use of the medium supplemented with IGF-I/hFSH. However, the medium containing $\mathrm{T}_{4}(10) / / \mathrm{IGF}-\mathrm{I}$ showed an increase in oocyte diameter. It can be suggested that IGF-I has a relevant participation in the increase of follicular diameter, corroborating the results found earlier by Demeestere et al. (2005) and Martins et al. (2010). This effect seems to be linked to an increase of the mitotic rate of granulosa cells and an increase in oocyte size. Furthermore, it was demonstrated that IGF-I has a participation in the increase of DNA content, promoting functional integrity and stimulating steroidogenesis during the culture of preantral follicles of mice (Demeestere et al., 2005).

The increase in the follicular diameter due to the stimulation by IGF-I, in preantral follicles, has been shown in other species, like rats (Zhao et al., 2001) and cattle (Thomas et al., 2007). However, although it has a stimulatory effect on early follicular growth, McCaffery et al. (2000) highlighted the importance of the regulation mechanism, since, in cattle, inadequate exposure of preantral follicles to IGF-I has a negative effect on oocyte development. However, despite the beneficial effect shown in this study, there are still few studies regarding the issue, and the real role of IGF-I in the development of preantral follicles remains unclear.

According to Matos et al. (2007), ultrastructural evaluation is an efficient method for evaluating the morphodynamics of the ovarian follicle and can be considered an essential assessment to predict follicular quality after the in vitro culture of preantral follicles. Thus, after the evaluation by the transmission electron microscopy used in this work it can be seen that the follicles from fresh control, and those cultured for seven days in medium containing $T_{4}(20) / h F S H$ presented similar characteristics to the control, characterizing them as morphologically normal structurally. This fact can also be confirmed by comparing the characteristics found in the present study to those described by Celestino et al. (2009) and Lima et al. (2012), who outlined standards of normality and atresia to caprine preantral follicles cultured in vitro.

\section{Conclusions}

The addition of $\mathrm{T}_{4}$ associated with $\mathrm{hFSH}$ is beneficial for the in vitro development of preantral follicles of goats. Among the evaluated concentrations, the medium containing $\mathrm{T}_{4}(20) / \mathrm{hFSH}$ showed the best results, when survival, growth and ultrastructural aspects of caprine preantral follicles cultured in vitro for one and seven days were compared.

\section{Acknowledgements}

To CNPq for the financial support to the research. To CAPES for providing the scholarship to the Doctorate student. To the core of Microscopy and Microanalysis of UFV for the support in the ultrastructural analysis. 


\section{References}

ARUNAKUMARI, G.; VAGDEVI, R.; RAO, B.S. et al. Effect of hormones and growth factors on in vitro development of sheep preantral follicles. Small Ruminant Res, v.70, p. 93-100, 2007.

ARUNAKUMARI, G.; SHANMUGASUNDARAM, N.; RAO, V. $H$. Development of morulae from the oocytes of cultured sheep preantral follicles. Theriogenology, v.74, p. 884-894, 2010.

CECCONI, S.; BARBONI, B.; COCCIA, M.; MATTIOLI, M. In vitro development of sheep preantral follicles. Biol Reprod, v. 60, p. 594-601, 1999.

CECCONI, S.; ROSSI, G.; COTICCHIO, G.; MACCHARELLI, G.; BORINI, A.; CANIPARI, R. Influence of thyroid hormone on mouse preantral follicle development in vitro. Fertil Steril, v. 81, p. 919-924, 2004.

CELESTINO, J.J.H.; BRUNO,J.B.; LIMA-VERDE, I.B.; et al. Recombinant Epidermal Growth Factor Maintains Follicular Ultrastructure and Promotes the Transition to Primary Follicles in Caprine Ovarian Tissue Cultured In Vitro. Reproductive Sciences vol.16, p. 239-246, 2009.

CELESTINO, J.J.H., J.B. BRUNO, I.B. LIMA-VERDE, et al. Steady-state level of kit ligand mRNA in goat ovaries and the role of kit ligand in preantral follicle survival and growth in vitro. Mol Reprod Dev, v. 77, p. 231-240, 2010.

CHENG, S.Y.; LEONARD, J.L.; DAVIS, P.J. Molecular Aspects of Thyroid Hormone Actions. Endocrine Reviews, v. 31, n. 2, p.139170, 2010.

DEMEESTERE, I.; CENTNER, J.; GERVY, Y.; DELBAERE, A. Impact of various endocrine and paracrine factors on in vitro culture of preantral follicles in rodents. Reproduction, n. 130, p.147-156, 2005.

DONATO, M.A.M., K.L.A. SARAIVA, A.K.S. SILVA, M.I. WANDERLEY, C.A. PEIXOTO. Follicle development and luteal cell morphology altered by phosphodiesterase- 5 inhibitor. Micron, v. 40, p. $845-850,2009$.

GUTIERREZ, C.G.; RALPH, J.H.; TELFER, E.E.; WILMUT, I., WEBB, R. Growth and antrum formation of bovine antral follicles in long-term culture in vitro. Biol Reprod, v. 62, p.1322-1328, 2000.

LIMA, I.M.T.; CELESTINO, J.J.H.; FAUSTINO, L.R.; et al. Dynamic Medium Containing Kit Ligand and Follicle Stimulating Hormone Promotes Follicular Survival, Activation and Growth During Long-Term In Vitro Culture of Caprine Preantral Follicles. Cells Tissues Organs, v.195, p. 260-271, 2012.

LOUHIO, H.; HOVATTA, O.; SJOBERG, J.; TUURI, T. The effects of insulin, and insulin-like growth factors I and II on human ovarian follicles in long-term culture. Mol Hum Reprod, v. 6, p. 694-698, 2000.

MAO et al., Effects of Culture Medium, Serum Type, and Various Concentrations of Follicle-Stimulating Hormone on Porcine Preantral Follicular Development and Antrum Formation In Vitro. Biology of Reproduction, n. 67, p.1197-1203, 2002.

MARTINS, F.S.; CELESTINO, J.J.H.; SARAIVA, M.V.A. et al. Interaction between growth differentiation factor 9, insulin-like growth factor I and growth hormone on the in vitro development and survival of goat preantral follicles F.S. Braz J Med Biol Res, v. 43(8), p. 728-736, 2010.
MATOS, M. H. T., I. B. LIMA-VERDE, M. C. A. LUQUE, J. E. MAIA, J. R. V. SILVA, et al. Essential role of follicle stimulating hormone in the maintenance of caprine preantral follicle viability in vitro. Zygote, v. 15, p. 173-182, 2007.

MCCAFFERY, F.H.; LEASK, R.; RILEY, S.C.; TELFER, E.E. Culture of bovine preantral follicles in a serum-free system: markers for assessment of growth and development. Biology of Reproduction, v. 63, p. 267-273, 2000.

O'BRIEN, M.J.; PENDOLA, J.K.; EPPIG, J.J. A revised protocol for in vitro development of mouse oocytes from primordial follicles dramatically improves their developmental competence. Biol Reprod, v. 68, p.1682-1686, 2003.

PICTON, H.M.; HARRIS, S.E.; MURUVI, W.; CHAMBERS, E.L. The in vitro growth and maturation of follicles. Reproduction, $\mathrm{v}$. 136, p. 703-715, 2008.

RAJARAJAN, K.; RAO, B.S.; VAGDEVI, R.; TAMILMANI, G.; et al. Influence of various growth factors on in vitro development of goat preantral follicles. Small Rumin Res, v. 63, p. 204-212, 2006.

RODRIGUES, G.Q.; SILVA, C.M.G.; FAUSTINO, L.R. et al. Efeito de diferentes concentrações de hormônio folículo estimulante recombinante sobre o desenvolvimento in vitro de folículos pré-antrais caprinos e ovinos isolados. Acta Veterinaria Brasilica (UFERSA), v. 4, p. 144-152, 2010.

SARAIVA, M.V.A.; CELESTINO, J.J.H.; ARAÚJO, V.R.; CHAVES, R.N.; ALMEIDA, A.P.; LIMA-VERDE, I.B.; et al. Expression of follicle-stimulating hormone receptor (FSHR) in goat ovarian follicles and the impact of sequential culture medium on in vitro development of caprine preantral follicles. Zygote, p. 1-10, 2010.

SAS Institute Inc 2002: SAS/STAT ${ }^{\circledR} 9.0$ User's guide. Cary, NC: SAS Institute Inc.

SERAKIDES, R.; NUNES, V. A.; NASCIMENTO, E.; RIBEIRO, A. F. C.; SILVA C. M. Foliculogênese e esteroidogênese ovarianas em ratas adultas hipertireóideas. Arquivo Brasileiro de Endocrinology e Metabologia, v. 45, p. 258-264, 2001.

SILVA, J. R. V.; VAN DEN HURK, R.; MATOS, M. H. T.; SANTOS, R. R.; PESSOA, C.; MORAES, M. O.; FIGUEIREDO, J. R. Influences of $\mathrm{FSH}$ and EGF on primordial follicles during in vitro culture of caprine ovarian cortical tissue. Theriogenology, v. 61, p.1691-1704, 2004.

SILVA, J.R.V.; THARASANIT, T.; TAVERNE, M.A.M.; et al. The activin-follistatin system and in vitro esrly development in goats. J. Endocrinol, v.189, p.113-125, 2006.

THOMAS, F. H.; ETHIER, J. F.; SHIMASAKI, S.; VANDERHYDEN, B. C. Follicle-stimulating hormone regulates oocyte growth by modulation of expression of oocyte and granulosa cell factors. Endocrinology, v.146, p. 941-949, 2005.

THOMAS, F.H.; CAMPBELL, B.K.; ARMSTRONG, D.G.; TELFER, E.E. Effects of IGF-I bioavailability on bovine preantral follicular development in vitro. Reproduction, v.133, p.1121-1128, 2007.

ZHAO, J.; DORLAND, M.; TAVERNE, M.A.M. et al. In vitro culture of rat preantral follicles with emphasis on follicular interactions. Molec Reprod Dev, v. 55, p. 65-74, 2000.

ZHAO, J.; TAVENE, M.A.M.; VAN DER WEIJDEN, G.C. et al. Insulin-like growth factor-I (IGF-I) stimulates the development of cultured rat pre-antral follicles. Mol Reprod Develop, v. 58, p. 287296, 2001. 